\title{
Загальні принципи побудови і функціонування реабілітаційної клініки у класичному університеті
}

\author{
Лях Ю. Є., Уляницька Н. Я., Якобснон О. О., Лях М. В. \\ Східноєвропейський національний університет імені Лесі Українки, м. Луцьк, Україна
}

Вступ. Підготовка фахівців у галузі охорони здоров'я з фізичної терапії та ерготерапії передбачає наявність клінічної бази для забезпечення практичного освоєння необхідних знань та навичок. Кафедри фізичної терапії та ерготерапії змушені укладати договори на спеціальну підготовку 3 медичними закладами та приватними реабілітаційними центрами. Але студенти практично не мають можливості працювати самостійно 3 пацієнтами, що суттєво знижує цінність випускника кафедри на ринку праці. Ця ситуація негативно впливає на підготовку наукових кадрів та виконання конкурентоспроможних наукових досліджень у галузі. Позбутися цих недоліків можливо через створення власної університетської реабілітаційної клініки. Така база може поєднати в собі навчання, практику, наукові дослідження і сам процес фізичної терапії пацієнтів.

Методи дослідження: аналіз та узагальнення даних науково-методичної та спеціальної літератури, логіко-теоретичний аналіз та системний підхід.

Результати дослідження. Для забезпечення реабілітаційно-діагностичного процесу, підготовки, перепідготовки і підвищення кваліфікації науково-педагогічних кадрів, а також проведення науково-дослід- ної роботи, навчання студентів створено клініку з відділеннями фізіотерапії, ерготерапії та фізичної терапії, телемедицини, ЛФК, бальнеології. Основні завдання і напрями діяльності: організація і надання реабілітаційної допомоги пацієнтам; розробка і впровадження реабілітаційних технологій, клінічних рекомендацій, стандартів, забезпечення умов для оволодіння студентами практичних навичок; максимальне використання сучасних інформаційних технологій; створення і впровадження конкурентоспроможних реабілітаційних технологій.

Висновки. Практична підготовка спеціалістів на базі клініки дозволяє створити мультидисциплінарну команду і поєднати педагогічний, науково-дослідний та лікувальний процеси.

Перспективи подальших досліджень. Дана модель передбачає використання міжнародної класифікації функціонування (МКФ), застосування методів оцінки вимірювання структурних змін та порушених функцій організму, трактування отриманої інформації, демонструючи доказове прийняття рішень.

Ключові слова: фізична терапія, ерготерапія, університетська реабілітаційна клініка. 